\title{
Annealing Effect on the Microstructure and Mechanical Properties of AA 5182 Aluminum Alloy
}

\author{
Daniel Marinho Filizzola ${ }^{\mathrm{b}}$, Thaís da Silva Santos ${ }^{\mathrm{a}}$, Adalberto Gomes de Miranda \\ João Carlos Martins da Costa ${ }^{\mathrm{a}}{ }^{\circledR}$, Nayra Reis do Nascimento ${ }^{\mathrm{c}}$, Marcos Dantas dos Santos, \\ Roger Hoel Bello , Gilberto Garcia del Pino ${ }^{\mathrm{b}}$,José Costa de Macêdo Neto * \\ ${ }^{\mathrm{a}}$ Universidade Estadual do Amazonas, Faculdade de Engenharia, Departamento de Engenharia de \\ Materiais, Avenida Darcy Vargas, 1200, Parque Dez de Novembro, CEP 69065-020, Manaus, AM, Brasil. \\ ${ }^{\mathrm{b}}$ Universidade Estadual do Amazonas, Faculdade de Engenharia, Departamento de Engenharia \\ Mecânica, Avenida Darcy Vargas, 1200, Parque Dez de Novembro, CEP 69065-020, Manaus, AM, Brasil. \\ ${ }^{\text {'} U n i v e r s i d a d e ~ E s t a d u a l ~ d e ~ C a m p i n a s, ~ F a c u l d a d e ~ d e ~ E n g e n h a r i a ~ Q u i ́ m i c a, ~ D e p a r t a m e n t o ~ d e ~}$ \\ Engenharia de Materiais e Bioprocessos, Rua Albert Einstein, 500, Cidade Universitária Zeferino Vaz, \\ Barão Geraldo, CEP 13083-852, Campinas, SP, Brasil.
}

Received: December 01, 2020; Revised: February 12, 2021; Accepted: April 14, 2021

\begin{abstract}
The properties of aluminum alloys can be improved by the processing conditions that cause changes in the microstructure and by the addition of alloy elements. In order to understand the physical behavior and mechanical properties of aluminum alloys, it is important to be aware of some of the microstructural characteristics. Some of these characteristics are the morphology, alloy elements, volume and size, and second phase. In this study, we analyzed the effect of annealing on the mechanical and microstructural properties of the laminated AA 5182 aluminum alloy, when subjected to different annealing conditions. The alloy was heated to temperatures of $50^{\circ} \mathrm{C}, 100^{\circ} \mathrm{C}, 150^{\circ} \mathrm{C}, 200^{\circ} \mathrm{C}, 250^{\circ} \mathrm{C}$ and $300^{\circ} \mathrm{C}$ for 10 minutes and left to cool naturally. The evolution of the microstructure was characterized by optical and electronic microscopy with EDS, and, to obtain the mechanical properties, a tensile test was performed and the fractures were subsequently analyzed. The results showed that the heat treatment used reduced the amount of second phase particles and this influenced the mechanical properties.
\end{abstract}

Keywords: AA 5182 aluminum alloy, Annealing, Mechanical Properties, Microstructure.

\section{Introduction}

Aluminum alloys are widely used in the areas of packaging, electronic technology, automotive body structure, engines and wheels, and wind and solar power generation, among others, due to advantages such as high specific strength, high processability, corrosion resistance ${ }^{1}$, high conductivity, and ease of recycling ${ }^{2}$. The mechanical properties of aluminum alloys vary in accordance with their applications, and heat treatments are used to modify the microstructures, which has an effect on their properties ${ }^{3}$.

Aluminum alloys are distinguished by their chemical composition, each of which has a specific application. The 2xxx series has $\mathrm{Cu}$ as its main element and is used in aviation and aerospace. The $3 \mathrm{xxx}$ series comprises $\mathrm{Mn}$ as its main element and isutilized in sheets for civil construction and fins. In 6xxx series, the main elements are $\mathrm{Mg}$ and $\mathrm{Si}$ and applications are in tools and the automotive industry. The alloy of the $5 \mathrm{xxx}$ series possessesMg as its main element and, among its variations, the alloy AA5182 is highlighted here due to its use in can end stock (CES). The strength of the non-heat treatable AA 5xxx series aluminum alloy is due to a combination of solid solution hardening with

*e-mail: jmacedo@uea.edu.br
$\mathrm{Mg}$ and dispersion hardening by $\mathrm{Mn}$ and other alloying elements in the formation of dispersoids ${ }^{4,5}$. Another type of increase in mechanical strength of this aluminum series is due to plastic deformation which affectsthe grain size $\mathrm{e}^{6}$, displacement density ${ }^{7}$ and texture developed during the deformation process ${ }^{8}$.

Beverage cans are produced in aluminum and are composed of two parts, the body (cup), which is usually made from AA 3004, and the lid, which is madefrom AA 5182. The manufacturing process of the lids is carried out by cold forming thin sheets $(0.208 \mathrm{~mm}$ thickness). To maintain the quality of the product,either annealing or accelerated aging is carried out,which simulates six months of exposure of the final product to normalenvironmental conditions. Then, the mechanical buckle and manual lid opening tests are performed. Figure 1 shows the finished product and the "residual metal" region in which the annealing heat treatment affects. The aluminum sheets used in this study are used in the manufacture of packaging caps.

In the search for better performance of products obtained from AA 5182 aluminum, several studies have sought to understand the microstructural and mechanical changes of this alloy when subjected to the annealing process. 


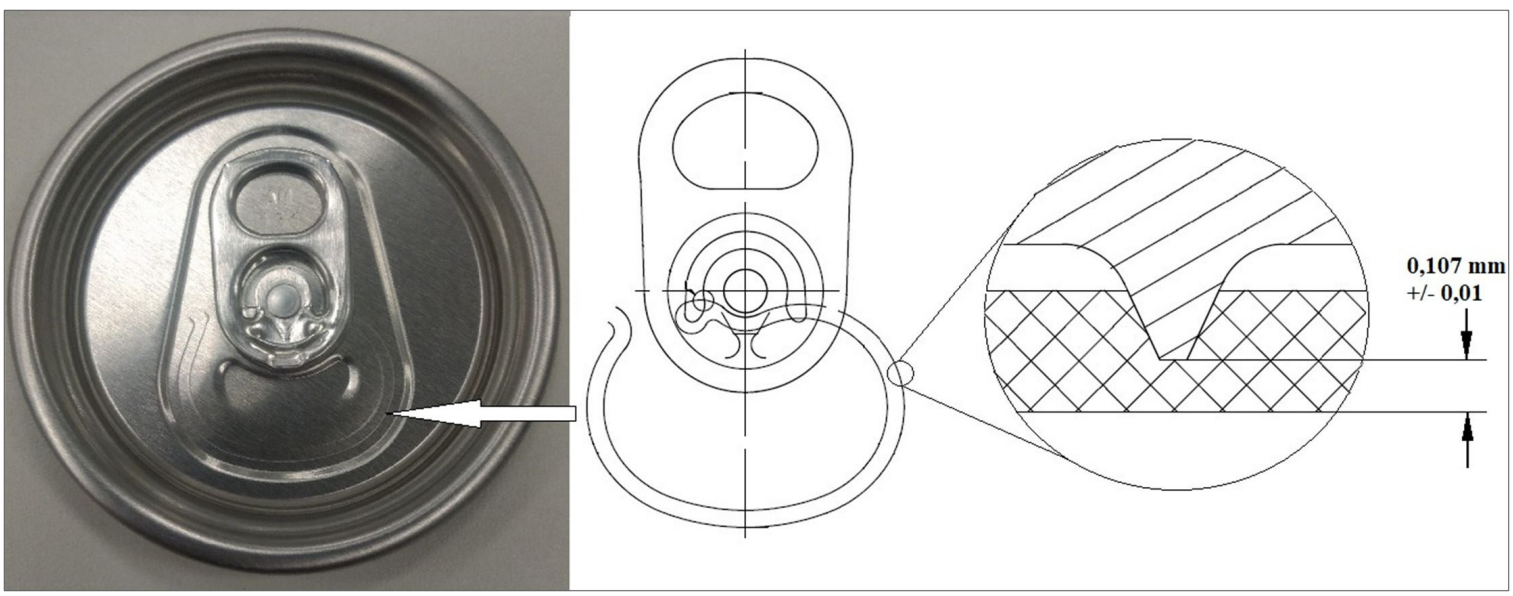

Figure 1. shows the details of the finished product and the "score" point at which the heat treatment is effective (Image: author).

Zhang et al. ${ }^{9}$ submitted cold-rolled AA 5182 alloy to $454^{\circ} \mathrm{C}$ and $540{ }^{\circ} \mathrm{C}$ and the effect on the initial recrystallization grain and mechanical properties were investigated. The authors found that the fine-grained alloy recrystallized faster and more homogeneously. The results showed that strength and flow limits were reduced for those with fine and coarse grains by increasing the annealing temperature.

Another study showed the effect of annealing and hot rolling on the chemical composition and morphology of AA5182 alloy dispersoids used in automobiles. For the heat treatment, temperatures of $530{ }^{\circ} \mathrm{C}$ for $3 \mathrm{~h}$ were used, followed by cooling in the oven for $1 \mathrm{~h}$ and $480{ }^{\circ} \mathrm{C}$ for $2 \mathrm{~h}$. After the homogenization annealing, dispersoids containing finely dispersed Fe and $\mathrm{Mn}$ were obtained ${ }^{10}$.

In another study, a sheet of AA5182 aluminum alloy was annealed at $454^{\circ} \mathrm{C}$ for $3 \mathrm{~h}$ and another, a sheet of direct-chill (DC), was cold rolled and annealed at $260^{\circ} \mathrm{C}$ for $2 \mathrm{~h}, 288^{\circ} \mathrm{C}$ for $10 \mathrm{~min}$ and $343{ }^{\circ} \mathrm{C}$ for $10 \mathrm{~s}$. The kinetics and texture of recrystallization were analyzed. The authors noted that the texture depends heavily on the annealing temperature. At low annealing temperatures, the recrystallization texture was characterized by an $\mathrm{R}$ orientation and a weak cube orientation. At high annealing temperatures the texture of recrystallization was entirely by the cube component ${ }^{11}$.

This study shows the changes that occurred in the microstructure and mechanical properties of AA5182 aluminum alloy sheets after annealing with temperatures of $50{ }^{\circ} \mathrm{C}$, $100^{\circ} \mathrm{C}, 150{ }^{\circ} \mathrm{C}, 200^{\circ} \mathrm{C}, 250^{\circ} \mathrm{C}$ and $300^{\circ} \mathrm{C}$ for 10 minutes. Microstructural characterization was performed by optical and electronic microscopy with energy dispersive spectroscopy (SEM-EDS). Details of the behavior of the sheet fractures that were obtained by the tensile test were also shown by electron microscopy (SEM-EDS).

\section{Materials and Methods}

Materials: The aluminum alloy used was AA 5182 (Al$\mathrm{Mg}$ ), which was cold rolled and had a of thickness $0.208 \mathrm{~mm}$ $\pm 0.005 \mathrm{~mm}$. This was supplied in the form of $32 \times 29.5 \mathrm{~cm}$ plates (Figure 2b).
Chemical composition: For the analysis of the composition, optical emission spectroscopy was performed (Spectro, model MaxxLMF15). Table 1 shows the chemical composition of AA 5182 alloy. Three readings were performed on the plate (Figure $2 \mathrm{c}$ ) and the mean and standard deviation were calculated. The main elements of this alloy are $\mathrm{Si}, \mathrm{Fe}, \mathrm{Cu}$, $\mathrm{Mn}, \mathrm{Mg} \mathrm{Zn}$ and Ti, and magnesium is the principal element of this alloy. The percentage of magnesium in the samples are not in accordance with the literature for this type of alloy ${ }^{12}$.

Heat treatment: The heat treatment used was that of annealing, which was performed at temperatures of 50 , $100,150,200,250,300^{\circ} \mathrm{C}$, with a fixed time of 10 minutes for each temperature (Figure 2a). For this step, we used a Quimis oven (model Q318M).The annealing temperatures of AA5182 aluminum were based on the temperatures that the industry already uses, i.e., between 90 and $150{ }^{\circ} \mathrm{C}$.

Tensile strength test: To perform the tensile strength test, the samples were obtained by manual cutting following the NBR ISO 6892:2002 standard. Four test pieces were cut for each temperature. Figures $2 \mathrm{a}$ show the samples before manual cutting. For the tensile strength test, we used an Instron machine (model 5984) and the test was speed $2 \mathrm{~mm} /$ min, at an ambient temperature of $25^{\circ} \mathrm{C}$.

Metallography: The samples were cold embedded in silicone molds using acrylic powder resin together with Forte $l^{\circledR}$ catalyst. For polishing, $0.3 \mu \mathrm{m}$ alumina was used and there was no need to perform sanding or chemical attack. The ASTM E-3:80 was used for the analysis. The microstructure images were captured using an Olympus optical microscope (model CX31) and Moticam Plus ${ }^{\circledR}$ image capture software. Figures $3 \mathrm{a}, \mathrm{b}$ and $\mathrm{c}$ show the samples used for metallography and microscopy.

Scanning electron microscopy (SEM): To obtain the images of the fractures, the tested samples were manually cut at $3 \mathrm{~cm}$ parallel to the faces of the fractures. Then, the samples were inserted vertically into a sample holder and metallized for 4 minutes using a Jeol metallizer (Model: DII-29010SCTR Smart coater) to improve the quality of the images. For precipitate images, the samples used for optical microscopy were metallized before SEM analysis. To obtain the images by SEM, a Jeol microscope (Model: JSM - IT500HR) was used. 


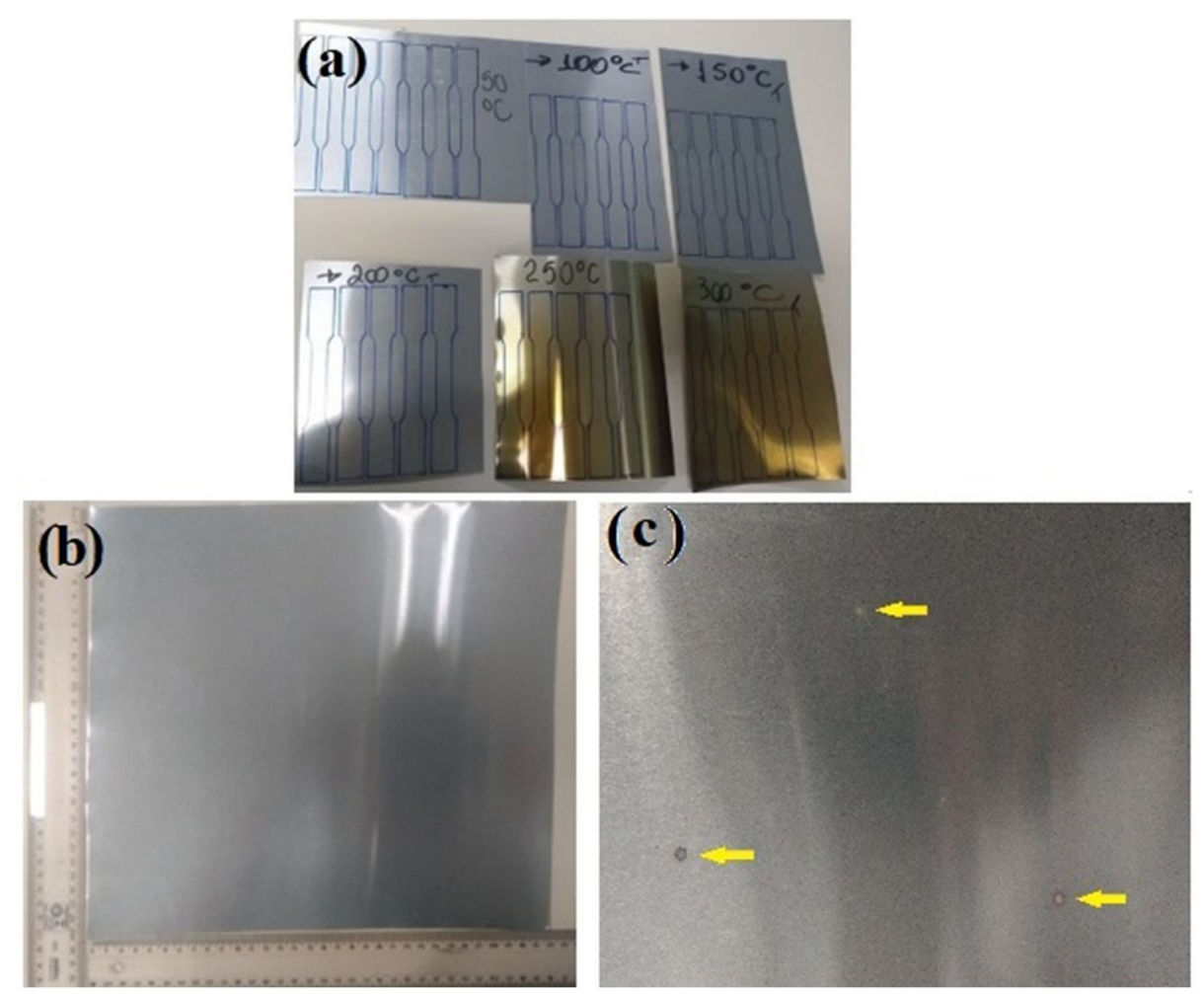

Figure 2. (a) Plates after heat treatments, (b) sheet metal provided for the study, (c) site of chemical composition measurements using optical emission spectroscopy.

Table 1. Chemical composition of the aluminum alloy (\%).

\begin{tabular}{|c|c|c|c|c|c|}
\hline Elements /Measuments & 1 & 2 & 3 & Mean & SD \\
\hline $\mathbf{S i}$ & 0.106 & 0.110 & 0.128 & 0.115 & 0.058 \\
\hline $\mathbf{F e}$ & 0.294 & 0.292 & 0.337 & 0.308 & 0.155 \\
\hline $\mathrm{Cu}$ & 0.087 & 0.087 & 0.088 & 0.087 & 0.044 \\
\hline Mn & 0.455 & 0.452 & 0.492 & 0.466 & 0.234 \\
\hline Mg & 3.600 & 3.550 & 3.170 & 3.440 & 1.731 \\
\hline $\mathbf{Z n}$ & 0.082 & 0.090 & 0.098 & 0.090 & 0.045 \\
\hline Ti & 0.041 & 0.046 & 0.051 & 0.046 & 0.023 \\
\hline $\mathrm{Cr}$ & 0.015 & 0.017 & 0.033 & 0.022 & 0.013 \\
\hline $\mathbf{N i}$ & 0.024 & 0.031 & 0.042 & 0.032 & 0.018 \\
\hline Ag & 0.001 & 0.001 & 0.004 & 0.002 & 0.001 \\
\hline B & 0.005 & 0.006 & 0.008 & 0.006 & 0.003 \\
\hline $\mathrm{Be}$ & 0.000 & 0.000 & 0.000 & 0.000 & 0.000 \\
\hline $\mathbf{B i}$ & 0.021 & 0.025 & 0.031 & 0.026 & 0.014 \\
\hline $\mathrm{Ca}$ & 0.005 & 0.004 & 0.007 & 0.006 & 0.003 \\
\hline Cd & $<0.00010$ & $<0.00010$ & $<0.00010$ & $<0.00010$ & $<0.00010$ \\
\hline $\mathrm{Co}$ & 0.024 & 0.023 & 0.033 & 0.027 & 0.014 \\
\hline Ga & 0.027 & 0.029 & 0.045 & 0.034 & 0.019 \\
\hline $\mathrm{Hg}$ & $<0.0020$ & $<0.0020$ & $<0.0020$ & $<0.0020$ & $<0.0020$ \\
\hline La & 0.010 & 0.013 & 0.016 & 0.013 & 0.007 \\
\hline $\mathbf{L i}$ & 0.225 & 0.299 & 0.371 & 0.298 & 0.161 \\
\hline $\mathrm{Na}$ & 0.002 & 0.002 & 0.003 & 0.002 & 0.001 \\
\hline $\mathbf{P}$ & $<0.0010$ & $<0.0010$ & $<0.0010$ & $<0.0010$ & $<0.0010$ \\
\hline $\mathbf{P b}$ & 0.061 & 0.057 & 0.078 & 0.065 & 0.034 \\
\hline Sn & 0.058 & 0.071 & 0.092 & 0.074 & 0.039 \\
\hline $\mathrm{Sr}$ & 0.003 & 0.004 & 0.005 & 0.004 & 0.002 \\
\hline $\mathbf{V}$ & 0.025 & 0.027 & 0.029 & 0.027 & 0.014 \\
\hline $\mathbf{Z r}$ & 0.0459 & 0.0473 & 0.0484 & 0.0472 & 0.024 \\
\hline $\mathbf{A l}$ & 94.800 & 94.700 & 94.800 & 94.767 & 47.383 \\
\hline
\end{tabular}



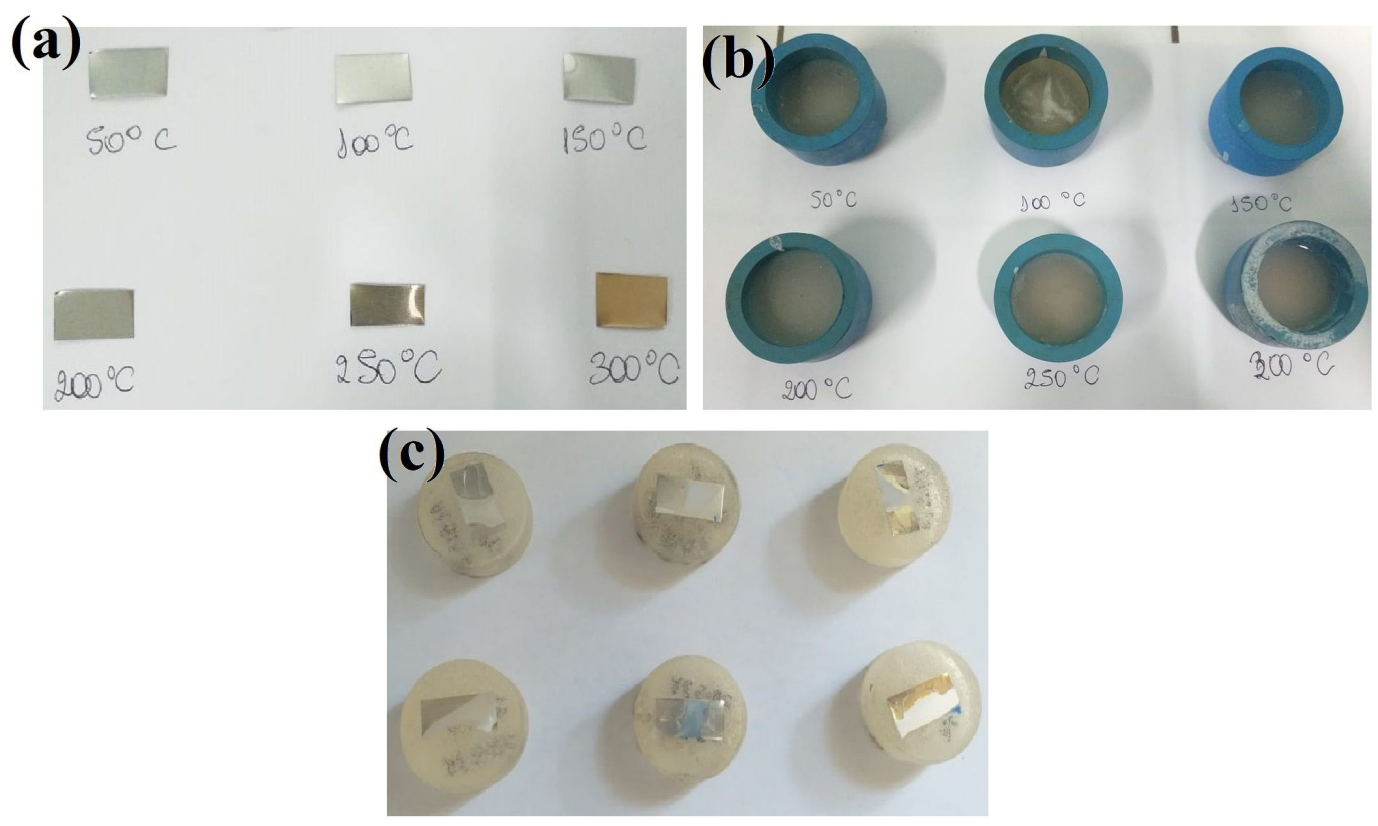

Figure 3. AA 5182 alloy heated to $50{ }^{\circ} \mathrm{C}, 100{ }^{\circ} \mathrm{C}, 150{ }^{\circ} \mathrm{C}, 200{ }^{\circ} \mathrm{C}, 250{ }^{\circ} \mathrm{C}$ and $300{ }^{\circ} \mathrm{C}$ for $10 \mathrm{~min}$. (a) cut samples, (b) samples in the molds with the resin during the curing process, (c) cold embedded samples.

\section{Results and Discussion}

\subsection{Tensile strength test}

Figures $4 \mathrm{a}, \mathrm{b}$ and $\mathrm{c}$ show the behavior of mechanical properties as a result of annealing temperatures of 50 , $100,150,200,250$ and $300^{\circ} \mathrm{C}$. In Figure $4 \mathrm{a}$, it is possible to observe that up to $200{ }^{\circ} \mathrm{C}$ there was a gentle reduction in the resistance limit and an increase in elongation. Between the temperatures of 200 and $250^{\circ} \mathrm{C}$, there was a greater reduction in the resistance limit and an increase in elongation. In Figure $4 \mathrm{~b}$, it can be observed that between the temperatures of 200 and $250{ }^{\circ} \mathrm{C}$, there was a reduction in the yield stress and elastic modulus. As the annealing temperature increased, a gradual reduction of the yield stress and resistance limit occurred due to the recovery effect. Between the temperatures of 200 and $250{ }^{\circ} \mathrm{C}$, there was a reduction in the yield stress, resistance, elastic modulus, and a drastic increase in elongation. This behavior was due to the occurrence of the beginning and end of recrystallization which reduces the density of dislocation in the alloy ${ }^{13}$. After the temperature of $250{ }^{\circ} \mathrm{C}$, behavior of the yield stress, resistance and elastic modulus was constant $t^{9,11,14}$. In Figure $4 c$, it is observed that, between the temperatures of 200 and $250{ }^{\circ} \mathrm{C}$, there was a reduction in the load and an increase in the rupture time, which indicates the occurrence of the beginning and end of recrystallization.

\subsection{Microstructures}

Figure 5 shows the SEM-EDS image of the dispersoids of AA5182alloy heated to $250^{\circ} \mathrm{C}$. Depending on the temperature, time and cooling classification during heat treatment, the dispersoids precipitate with different morphologies, including spheroidized forms, strips, rhomboids and plates ${ }^{15}$. In Figure 5, three types of morphologies of dispersoids are observed (1) $\mathrm{Al}(\mathrm{Si}, \mathrm{Mg})$ spheroidized $^{16}$, (2) $\mathrm{Al}(\mathrm{Fe}, \mathrm{Mn}, \mathrm{Cu})$ rhomboidal and Al (Mg,Mn) strips ${ }^{17}$.

Figures $6 \mathrm{a}, \mathrm{b}, \mathrm{c}, \mathrm{d}$, e and $\mathrm{f}$ show the evolution of the microstructures under heating to temperatures of 50, 100, $150,200,250$ and $300{ }^{\circ} \mathrm{C}$ respectively for 10 minutes. In Figure 6e, it is observed that there was an increase in the number of $\mathrm{Al}$ dispersoids (Fe, $\mathrm{Mn}$ ) when the temperature increased to $250{ }^{\circ} \mathrm{C}^{18}$. Figure $6 \mathrm{f}$ shows that there was a reduction in the number of dispersoids with the increase in temperature to $300{ }^{\circ} \mathrm{C}$. This reduction indicates that there was a dilution of the precipitates and an increase in the concentration of manganese in the matrix ${ }^{10}$. The increase in the quantity and size of dispersoids inhibits the recrystallization of the alloy ${ }^{19}$. This reflected in the mechanical properties of the alloy when heated to $300^{\circ} \mathrm{C}$, since it achieved greater elongation. As the dispersoids presented a non-coherent interface and high energy in the matrix, they caused greater mobility and promoted their dissolution ${ }^{20}$.

\subsection{Fractographic analysis}

Figures $7 \mathrm{a}, \mathrm{b}, \mathrm{c}, \mathrm{d}$, e and $\mathrm{f}$ show the fractures of the test samples when annealed at temperatures of 50, 100, 200, 250 and $300{ }^{\circ} \mathrm{C}$, respectively, for a period of 10 minutes. From the fractures, it can be observed that the increase in temperature caused a modification in their aspects, rupturingata $45^{\circ}$ angle with annealingat 50, 100 and $200{ }^{\circ} \mathrm{C}$, andat $90^{\circ}$ with annealing at 250 and $300^{\circ} \mathrm{C}$. The macrostructural modifications occurred with the increase in annealing temperature caused the modifications 

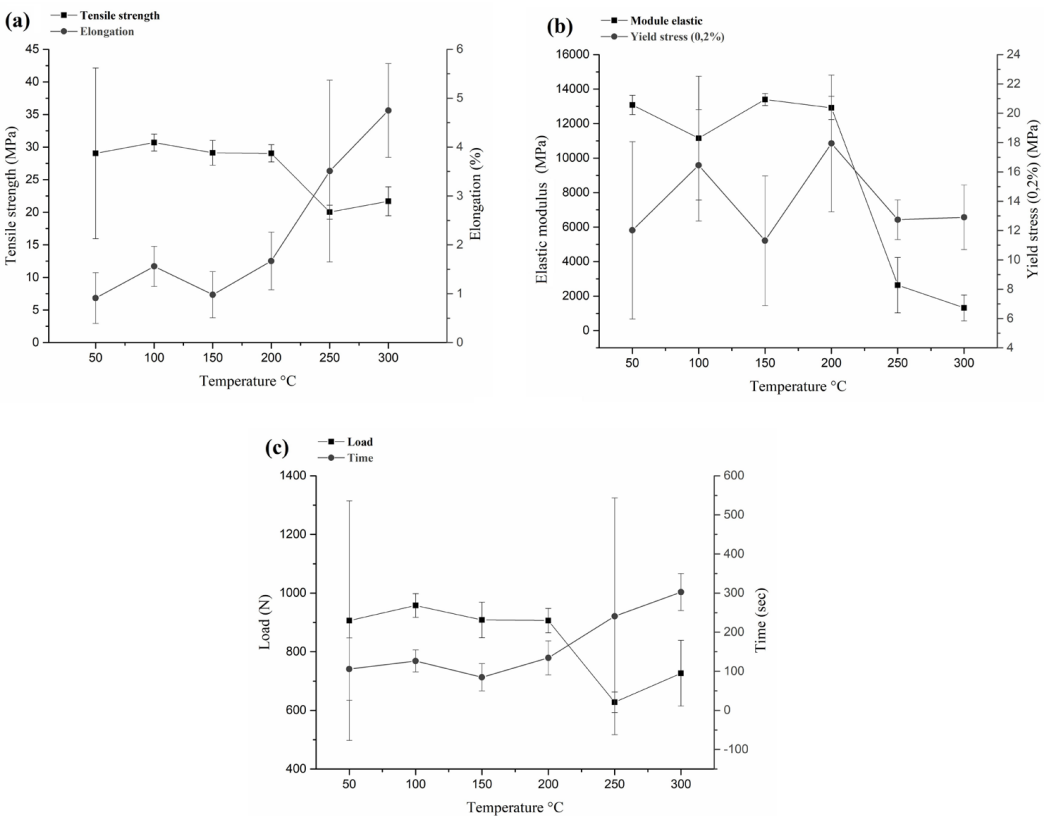

Figure 4. Relationship between tensile properties and annealing temperature: (a) Tensile strength and elongation, (b) elastic modulus and yield stress, and (c) load and rupture time of AA 5182 Alloy heated to $50^{\circ} \mathrm{C}, 100{ }^{\circ} \mathrm{C}, 150{ }^{\circ} \mathrm{C}, 200{ }^{\circ} \mathrm{C}, 250^{\circ} \mathrm{C}$ and $300^{\circ} \mathrm{C}$ for $10 \mathrm{~min}$.

in the aspect of fractures ${ }^{21}$. The reduction of the number of dispersoids for the sample annealed at $300{ }^{\circ} \mathrm{C}$ caused a fracture aspect with $90^{\circ}$.

Figures $8 \mathrm{a}, \mathrm{b}, \mathrm{c}, \mathrm{d}$, e and $\mathrm{f}$ show the images obtained using SEM of the fractures of the annealed samples at temperatures of $50,100,150,200,250$ and $300^{\circ} \mathrm{C}$, respectively. While Figures $9 \mathrm{a}-\mathrm{b}$ show the SEM-EDS fractures images just for 50 and $100{ }^{\circ} \mathrm{C}$. In all the images, large and small dimples are observed, which are characteristic of ductile fracture. It is possible to observe that the larger dimples decrease as the annealing temperature increases. The larger dimples are due to the higher triaxial state of stress. Constituent particles are seen on the inside of the dimples at all temperatures, but in some they are not seen and may have fallen or be on the opposite surface. In each particle, it is assumed that they are sites of nucleation of dimples due to particle fracture and/or dissociation between the particles and the matrix ${ }^{22,23}$. The fracture mechanisms found are similar for all recrystallization temperatures and consist of nucleation, growth and coalescence of voids around the constituent particles of $\mathrm{Al}(\mathrm{Fe}, \mathrm{Mg}), \mathrm{Al}(\mathrm{Mg})$ as seen in Figure 9. Nucleation occurred by creating a crack from a debondingin an interface of the second phase particles. The incipient cracks associated with the particles grow and coalesced by enlargement and linkage of the voids ${ }^{24}$.A large number of constituent particles, which appear to be small dispersoids, can be observed in the fractures. The size distribution of the constituent particles, as well as their distribution, are key elements that determine the tensile ductility of aluminum alloys ${ }^{22}$. It was observed that the number of dispersoids decreases as the annealing temperature increases, and this may have affected the elongation of the alloy.
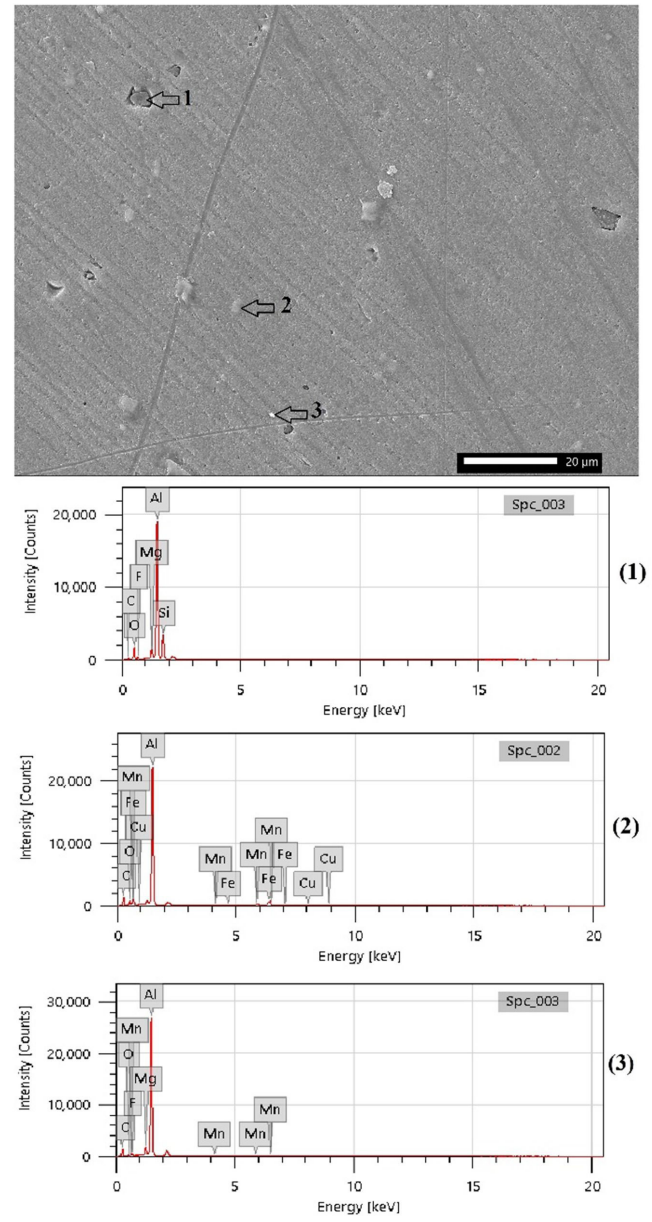

Figure 5. SEM-EDS precipitates of the aluminum alloy AA 5182heated to $250^{\circ} \mathrm{C}$ for $10 \mathrm{~min}$. 

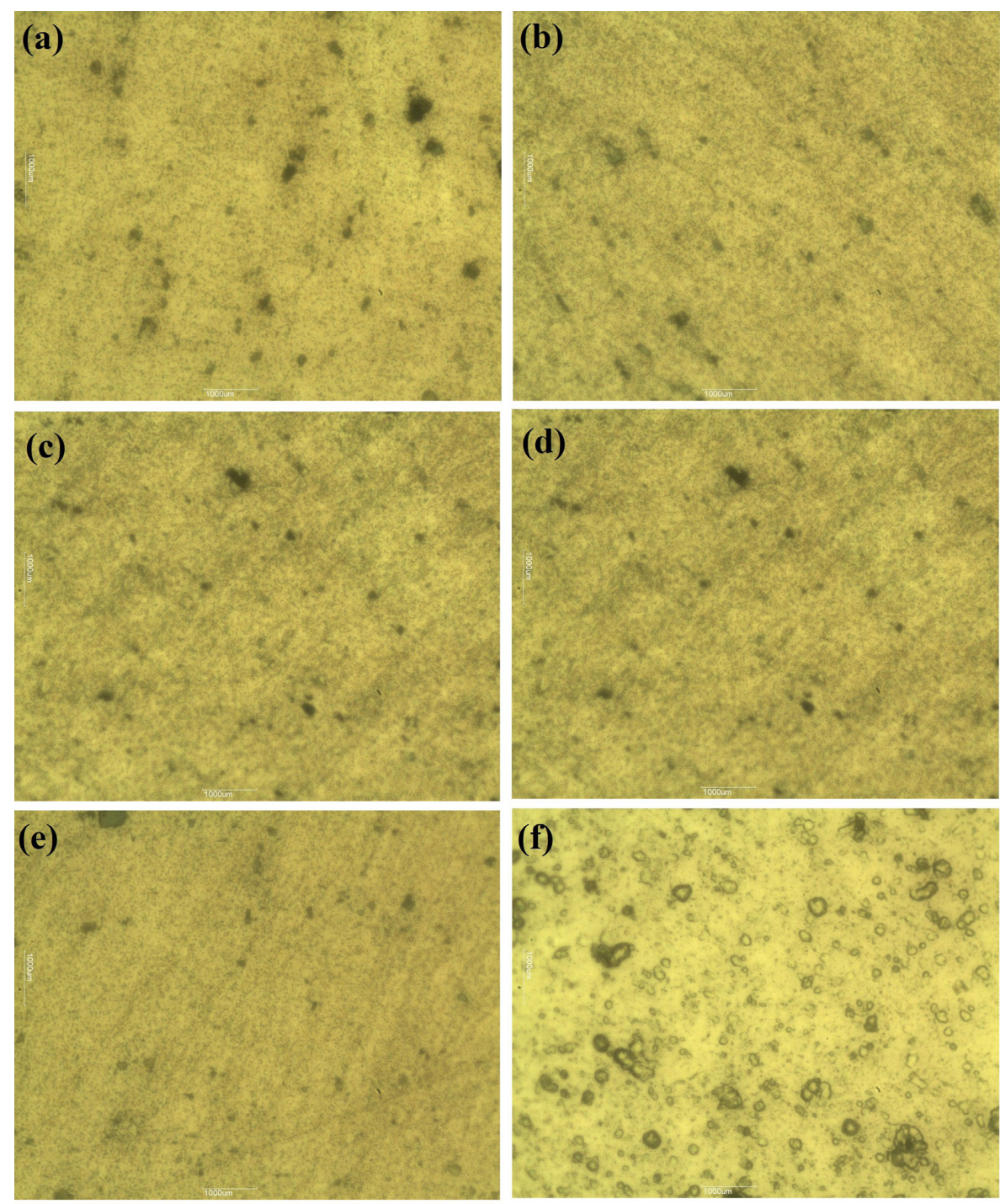

Figure 6. AA 5182 aluminum alloy microstructure heated to (a) $50{ }^{\circ} \mathrm{C}$, (b) $100{ }^{\circ} \mathrm{C}$, (c) $150{ }^{\circ} \mathrm{C}$, (d) $200{ }^{\circ} \mathrm{C}$, (e) $250{ }^{\circ} \mathrm{C}$, (f) $300{ }^{\circ} \mathrm{C}$ for a period of $10 \mathrm{~min}$. (polished and magnified to 400X).

\section{Conclusions}

The effect of annealing on the mechanical and microstructural properties of AA 5182 aluminum alloy was investigated and the following conclusions were obtained:

- Using optical spectroscopy, it was observed in the studied samples that the chemical composition of magnesium (the main characteristic element of AA 5182 alloy) presented below $14 \%$, which is the standard for this type of alloy.

- Between the temperatures of 200 and $250^{\circ} \mathrm{C}$, there was an inversion of the values of the related mechanical properties, limit of resistance and elongation, elastic modulus and yield stress, load and rupture time. This behavior was due to the beginning and end of recrystallization, which caused a relative reduction in mechanical resistance.

- After precipitation, there is a formation of extremely small and evenly distributed dispersoid particles.
Three different types of morphologies are observed for the dispersoids, $\mathrm{Al}(\mathrm{Si}, \mathrm{Mg})$ spheroidized, $\mathrm{Al}(\mathrm{Fe}, \mathrm{Mn}, \mathrm{Cu})$ rhomboidal and $\mathrm{Al}(\mathrm{Mg}, \mathrm{Mn})$ strip. For temperatures above $250^{\circ} \mathrm{C}$, there was a decrease in the number of dispersoids, which was due to the growth of the particles.

- It can be observed that the angle of rupture of fractures changes from $45^{\circ}$ to $90^{\circ}$, according to the temperature variation from 200 to $250{ }^{\circ} \mathrm{C}$. This occurred due to a reduction in the number of dispersoids.

- In all the samples, large and small dimples are observed, which are characteristic of ductile fracture. It is observed that the larger dimples reduce as the annealing temperature increases.

- A large amount of constituent particles of Al (Fe, $\mathrm{Mg})$ and $\mathrm{Al}(\mathrm{Mg})$ can be observed at the bottom of the dimples at all temperatures. Small dispersoids 


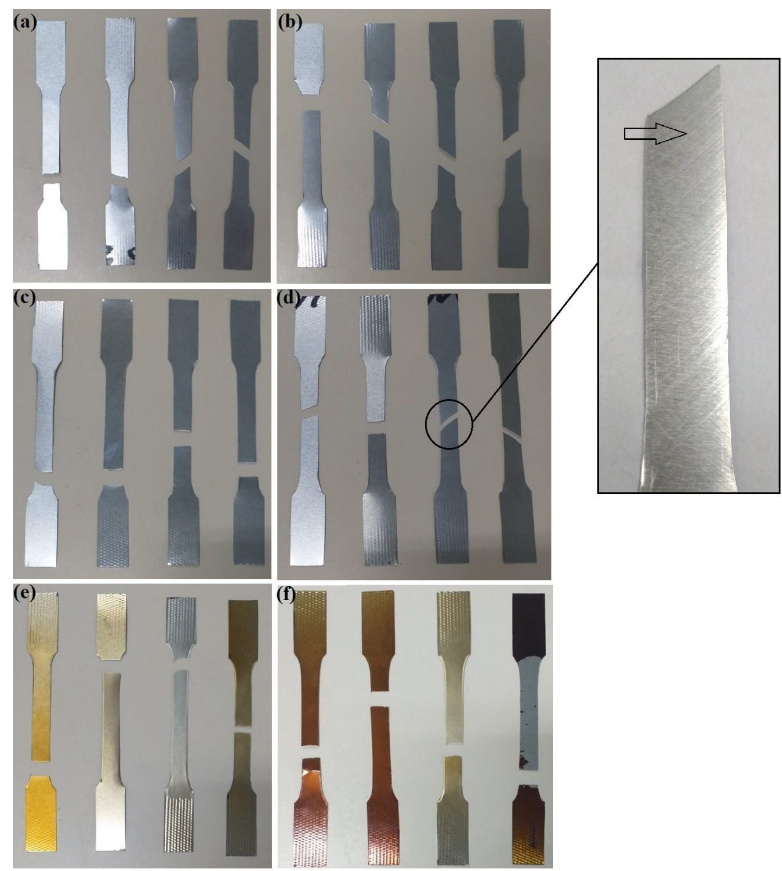

Figure 7. AA 5182 aluminum alloy samples heated for a period of $10 \mathrm{~min}$. Fracture of samples at different temperatures: a) $50{ }^{\circ} \mathrm{C}$, b) $100{ }^{\circ} \mathrm{C}$, c) 150 , d) $200^{\circ} \mathrm{C}$, e) $250^{\circ} \mathrm{C}$, and f) $300^{\circ} \mathrm{C}$.
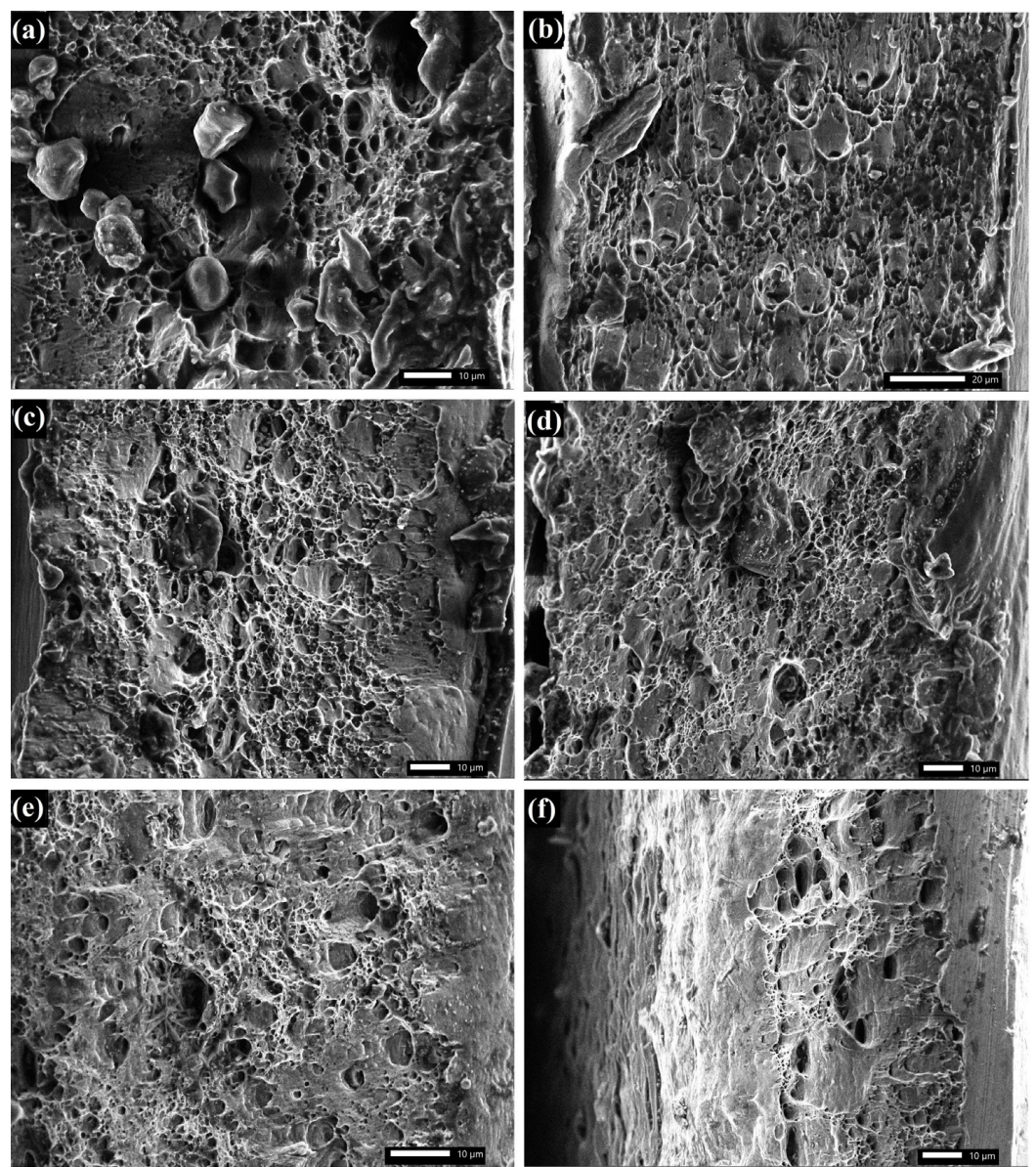

Figure 8. AA 5182 aluminum alloy heated for a period of $10 \mathrm{~min}$. SEM of tensile fracture tests of samples annealed at a) $50{ }^{\circ} \mathrm{C}$, b) $100^{\circ} \mathrm{C}$, c) $150{ }^{\circ} \mathrm{C}$, d) $200^{\circ} \mathrm{C}$, e) $250{ }^{\circ} \mathrm{C}$, f) $300^{\circ} \mathrm{C}$. 


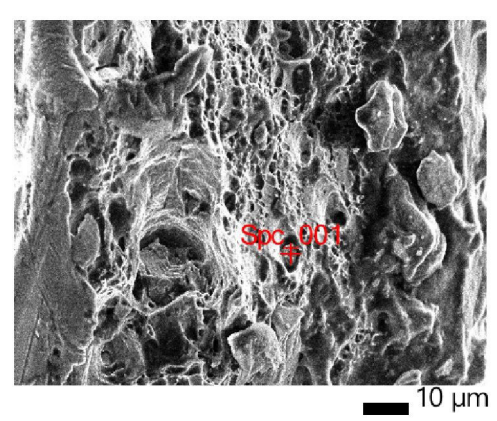

\section{(a)}
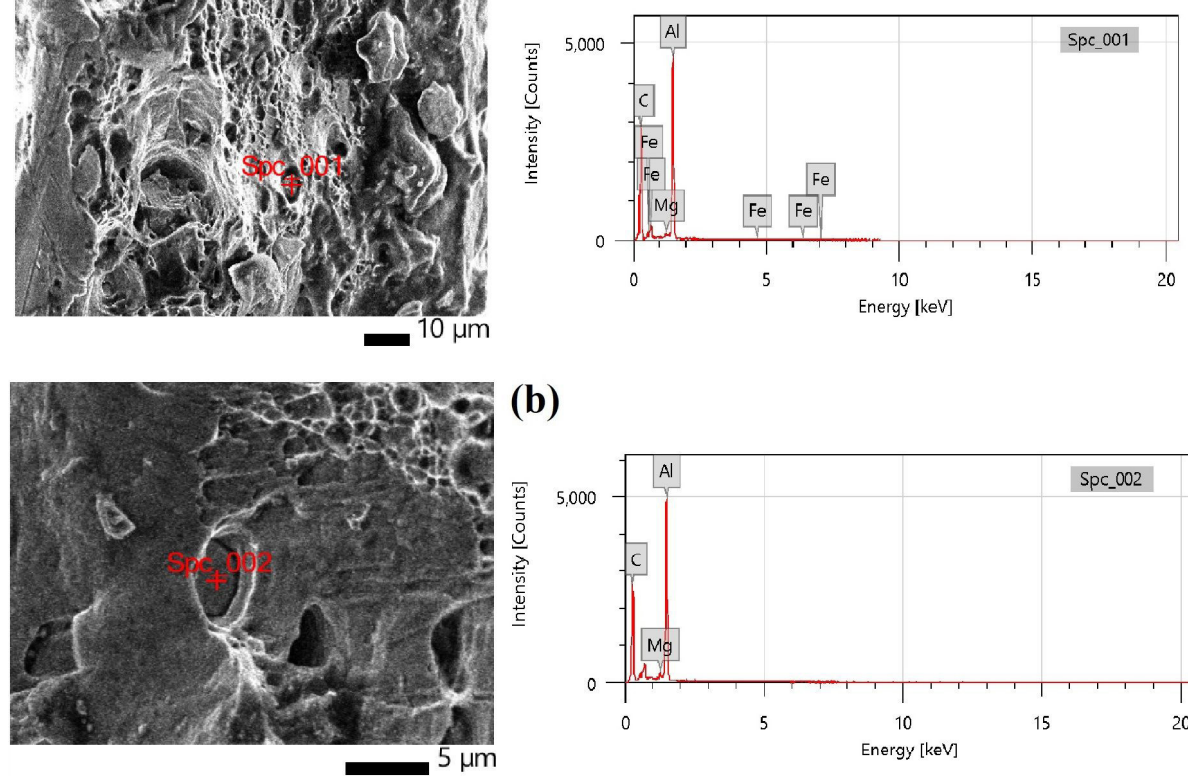

(b)

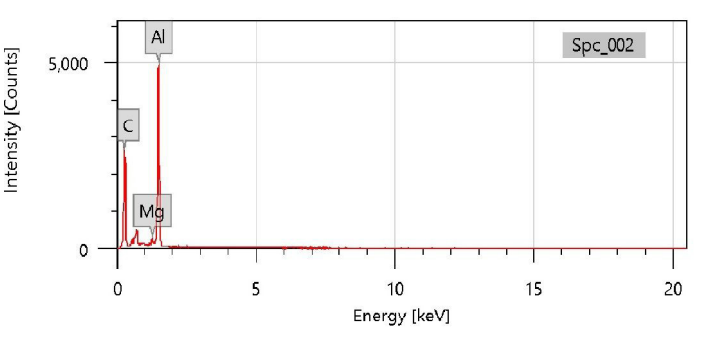

Figure 9. AA 5182 aluminum alloy heated for a period of $10 \mathrm{~min}$. SEM-EDS of the fractures in samples annealed at a) $50{ }^{\circ} \mathrm{C}$ and b) $100{ }^{\circ} \mathrm{C}$.

can apparently be seen, at the nucleation sites of the dimples due to particle fracture or discohesion, growth and coalescence of voids surrounding the particles and the matrix.

- The sizes of the constituent particles, as well as their distribution, are key elements for determining the tensile ductility of aluminum alloys.

- As the annealing temperature increases the number of dispersoids will decrease, affecting the elongation of the alloy.

\section{Acknowledgments}

The authors would like to thank the Multi-User Center for Analysis in Biomedical Phenomena (CAMBio) and Research and Development Laboratory (P\&DLab / UEA) at the Amazonas State University (UEA).

\section{References}

1. Mehdizade M, Soltanieh M, Eivani AR. Investigation of anodizing time and pulse voltage modes on the corrosion behavior of nanostructured anodic layer in commercial pure aluminum. Surf Coat Tech. 2019;358:741-52. http://dx.doi. org/10.1016/j.surfcoat.2018.08.046.

2. Varshney D. Aplicação e uso de diferentes ligas de alumínio no que diz respeito à trabalhabilidade, resistência e otimização dos parâmetros de soldagem. Ain Shams Eng. J. 2020;31:1-6.

3. She X, Jiang X, Zhang R, Wang P, Tang B, Du W. Study on microstructure and fracture characteristics of 5083 aluminum alloy thick plate. J Alloys Compd. 2020;825:153-960.

4. Stemper L, Tunes MA, Oberhauser P, Uggowitzer PJ. Agehardening response of $\mathrm{AlMgZn}$ alloys with $\mathrm{Cu}$ and $\mathrm{Ag}$ additions. Acta Mater. 2020;195:541-54.

5. Ebenberger P, Uggowitzer PJ, Gerold B. Effect of compositional and processing variations in new 5182-Type AlMgMn alloys on mechanical properties and deformation surface quality. Materials (Basel). 2019;12:1-21.

6. Howeyze M, Arabi H, Eivani AR, Jafarian HR. Strengthening of AA5052 aluminum alloy by equal channel angular pressing followed by softening at room temperature. Mater Sci Eng A. 2018;720:160-8. http://dx.doi.org/10.1016/j.msea.2018.02.054.

7. Howeyze M, Eivani AR, Arabi H, Jafarian HR, Park N. The effect of amount of pre-strain using equal channel angular pressing on softening response of AA5052 alloy. J Mater Res Technol. 2020;9:6682-95. http://dx.doi.org/10.1016/j.jmrt.2020.04.065.

8. Howeyze M, Eivani AR, Arabi H, Jafarian HR. Effects of deformation routes on the evolution of microstructure, texture and tensile properties of AA5052 aluminum alloy. Mater Sci Eng A. 2018;732:120-8. http://dx.doi.org/10.1016/j.msea.2018.06.081.

9. Zhang JX, Ma M, Liu WC. Effect of initial grain size on the recrystallization and recrystallization texture of cold-rolled AA 5182 aluminum alloy. Mater Sci Eng A. 2017;690:233-43. http://dx.doi.org/10.1016/j.msea.2017.03.015.

10. Engler O, Kuhnke K, Hasenclever J. Development of intermetallic particles during solidification and homogenization of two AA 5xxx series Al-Mg alloys with different $\mathrm{Mg}$ contents. J Alloys Compd. 2017;728:669-81. http://dx.doi.org/10.1016/j. jallcom.2017.09.060.

11. Liu WC, Zhai T, Morris JG. Effect of initial texture on the recrystallization texture of cold rolled AA 5182 aluminum alloy. Mater Sci Eng A. 2005;402:215-27.

12. ASM International. ASM handbook: properties and selection: nonferrous alloys and special-purpose materials. 10th ed. Materials Park: ASM International; 1990.

13. Najafi S, Eivani AR, Samaee M, Jafarian HR, Zhou J. A comprehensive investigation of the strengthening effects of dislocations, texture and low and high angle grain boundaries in ultrafine grained AA6063 aluminum alloy. Mater Charact. 2018;136:60-8. http://dx.doi.org/10.1016/j.matchar.2017.12.004.

14. Liu WC, Zhai T, Morris JG. Comparison of recrystallization and recrystallization textures in coldrolled DC and CC AA 5182 aluminum alloys. Mater Sci Eng A. 2003;358:84-93. 
15. Li YJ, Zhang WZ, Marthinsen K. Precipitation crystallography of plate-shaped Al6(Mn,Fe) dispersoids in AA5182 alloy. Acta Mater. 2012;60:5963-74.

16. Lentz OE, Martin GL. Characterization of second-phase particles in two aluminium foil alloys. J Alloys Compd. 2016;5:276-88.

17. Ratchev P, Verlinden B, Houtte P. Effect of preheat temperature on the orientation relationship of $(\mathrm{mn}, \mathrm{fe}) \mathrm{a} 16$ precipitates in an AA 5182 aluminiummagnesium alloy. Acta Mater. 1995;43:621-9.

18. Li YJ. A eutectoid phase transformation for the primary intermetallic particle from $\mathrm{Alm}(\mathrm{Fe}, \mathrm{Mn})$ to $\mathrm{Al}(\mathrm{Fe}, \mathrm{Mn})$ in AA5182 alloy. Acta Mater. 2004;52:2945-52.

19. Eivani AR, Zhou J, Duszczyk J. A new approach to incorporating the effect of nano-sized dispersoids on recrystallization inhibition into Monte Carlo simulation. Comput Mater Sci. 2012;54:370-7. http://dx.doi.org/10.1016/j.commatsci.2011.10.016.

20. Ratchev P, Verlinden B, van Houtte P. Effect of preheat temperature on the orientation relationship of $(\mathrm{Mn}, \mathrm{Fe}) \mathrm{Al} 6$ precipitates in an AA 5182 aluminium: magnesium alloy. Acta Metall Mater. 1995;43:621-9.

21. Hollinshead PA. Effect of preheat treatment on ingot structure and recrystallisation of brass component of rolling texture in hot rolled AA 5182. Mater Sci Technol. 2013;8:59-62.

22. Hannard F, Pardoen T, Maire E, Le Bourlot C, Mokso R, Simar A. Characterization and micromechanical modelling of microstructural heterogeneity effects on ductile fracture of 6xxx aluminium alloys. Acta Mater. 2016;103:558-72.

23. Frodal BH, Dæhli LEB, Børvik T, Hopperstad OS. Modelling and simulation of ductile failure in textured aluminium alloys subjected to compression-tension loading. Int J Plast. 2019;118:36-69.

24. Becker WT. Mechanisms and appearances of ductile and brittle fracture in metals. In: ASM International. ASM Handbooks online. Vol. 11. Materials Park: ASM International; 2000. p. 2909. https://doi.org/10.31399/asm.hb.v11.a0003538. 